\title{
POSITIVE ORGANIZATIONAL CULTURE AS A NEW TREND IN CROSS-CULTURAL MANAGEMENT. BASIC CONCEPTS
}

\author{
Kamila Mazur ${ }^{\mathrm{a}}$

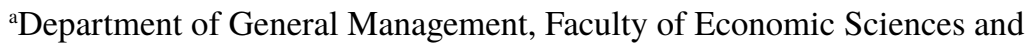 \\ Management, Nicolaus Copernicus University, Toruń, Poland, e-mail: \\ kamila.mazur@gmail.com
}

\begin{abstract}
The article presents the most popular concepts in intercultural management. So far, the majority of these concepts has focused on the study of differences arising from national foreign cultures and on the elimination of conflicts arising from these differences. A new perspective in the concept of intercultural management is looking at it through the prism of the positive values which create Positive Organizational Culture. This perspective assumes the Positive Organizational Potential. The last part is an attempt to describe the values which create a Positive Organizational Culture in the two culturally different countries: Japan and Poland.
\end{abstract}

Keywords: Positive Organizational Culture, Positive Organizational Potential, intercultural management, transnational corporations, culture, organizational culture

Paper type: Research paper

The last decades of the twentieth century showed managers of companies operating in the international market that it is necessary to develop global strategies. In the twenty-first century, these activities have become a priority. Management focuses on the modern management of research and development, manufacturing, marketing or finance. Today, we see a gap, a need to develop a modern organizational behaviour and human resource management, which will be prepared for the new conditions of global competition. The significant developments and changes that have occurred in this area of business but are still overlooked include the cultural aspect of organizational management.

Managers often perceive intercultural management as a marginal factor affecting the success of the company. However, the world organization can no longer be defined at the national level. Employees, suppliers, customers, all around the company comes from different parts of the world, while representing a distinct culture. Therefore, to work effectively with them, it is necessary to make intercultural management one of the priority areas of the company.

Quite a significant problem in developing knowledge and skills in the field of intercultural management, so managers and other staff in the company, is the 
POSITIVE ORGANIZATIONAL CULTURE

Kamila Mazur fact that previous publications have focused primarily on the U.S. experience: observation undergoing American managers and organizations, and on this basis intercultural management in the United States has been described. The researchers adopted the assumption that organizational behaviour in the U.S. remains universal at the global level, mostly ignoring the rest of the world's cultural diversity. But now managers no longer have the luxury of reducing the overall complexity to simple solutions based on universalism. They also do not have a comfort based on the belief that there is one right and proper management. Fortunately, experience has taught everyone that global cultural complexity is neither unpredictable nor random. Cultural differences and their impact on business operations follow systematic and predictable paths.

From the moment when the world of science and business realized how important culture management in business is, intercultural studies have started to occupy a prominent role in the field of management sciences. The company to continue its operations in the culturally diverse markets needs to (Karcz, 2001):

- $\quad$ understand the values desired by the customer;

- $\quad$ accept these values and at the same time resulting from them needs, to create an offer, as best suited to the customer;

- take into account the importance of goods and services and to communicate their advantages not only of the physical attributes, but also of symbolic;

- $\quad$ provide new values.

However, it is assumed that culture in which the company operates can affect the following (Karcz, 2001):

- the relationship between the firm and its current or potential customers; - intra-corporate relationships between units of multinational corporations, which are

- located in different parts of the world and employ culturally diversified staff; - the relationship between the actors playing on the market;

- models of the enterprise;

- the management of the organization.

At this point it seems reasonable and important for further considerations to define the concept of culture. Anthropologists, sociologists and scientists from many other areas of science are constantly debating the meaning of this term. The main problems of definition arose from the fact that it is an abstract concept, and usually different people understand them differently. For the purposes of this paper the author assumes that it is a set of learned beliefs, values, principles, norms, symbols and traditions that are common to a certain group of people. These mutually shared qualities make this group unique and separated. Culture is a dynamic phenomenon, which is forwarded to other units. To put this in shorter terms, culture is a lifestyle, customs and traditions of a group of people 
Literature in the field of the company science used term culture variously. Linda Smircich found that there are three basic ways to use this term in publications in the field of marketing and management:

- in cross-cultural studies it is an explaining factor which affects the various elements of management process, that is why is treated as an independent variable;

- in the general science of management the concept of organizational culture is used as a tool that can be skilfully manipulated to increase the beneficial effects of the financial results; (Smircich, 1983)

- in the organization ethnography, culture is a way to learn about business. It is a source of perspective in enabling the organization beyond the categories of economic or material (particularly symbolic elements, expressive and ideation) (Kostera, 2003).

It is crucial to distinguish between the organizational culture and culture. Indications and cultural determinants described above preserve a fundamentally different role in organizational cultures than in the national culture. The most famous studies of intercultural differences were carried out in the years 1985-1987 at IBM. The study was conducted under the auspices of the IRIC (Institute for Research on Intercultural Cooperation). Among IBM employees from different countries there were observed substantial differences between the general, fundamental values. Respondents who were alike in most characteristics, except nationality, thought completely different things to be good or bad, right or reprehensible, etc. These differences were very clear, though, that in terms of labour practices relating to all IBM employees are very similar to each other. IRIC project showed that the dependence of the values and practices at the national level is exactly opposite to the level of organization (Hofsyede, 2007).



Figure 1. The essence of cultural differences: the level of national culture, professional and organizational

Source: Hofstede (2007). 
POSITIVE ORGANIZATIONAL CULTURE

Kamila Mazur
Figure 1 shows that at the national level differences occur mainly in the sphere of values and are marginal in the field of practice. Conversely, at the organizational level differences appear in the sphere of practice.

IBM Research ${ }^{1}$ is a living example of how a multicultural company can be a one multinational corporation, and this situation requires the cooperation between cultures.

One way of training managerial staff in the multicultural management is to send them abroad to come in contact there, once worked with local people. What is important to emphasise that what should be assessed here is not only the execution of current tasks in a different cultural environment, but also the realization of long-term plans, such as selection and training of successors among the local staff to develop in them a sense of loyalty to the corporation and pride in being an employee and entering into cooperation throughout the environment in which the firm operates. Focusing on the global strategy and management from the perspective of people and cultures helps us understand the impact of national and indigenous culture on the functioning of the organization (Hofstede, 2007).

Intercultural management explains human behaviour in organizations around the world and shows you how to work with customers and staff emanating from many different cultures. Intercultural management describes and compares the organizational behaviour within countries and cultures. But the most important function is to improve intercultural management and more efficient interaction between co-workers, managers, top management team, customers, suppliers and strategic partners coming from different countries and cultures of the world. In this way, intercultural management at the company extends the reach of national management that could turn the current of international and intercultural because domestic / intra-cultural management is now seen as a limited subset of global intercultural management (Adler, 2002).

Onecan assume thatinterculturalmanagement generally takes placein twocases: -when themanagerisworkinginanothercountry(region)thanhis orherhomecountry; - when the manager works with people derived from diverse cultures (the international or intercultural environment) (Wójtowicz, 2004).

It is based on the assumption that culture has an impact on norms, values, attitudes and patterns of behaviour of all participants in the organization. Acting at the crossroads of cultures, it is necessary to pay attention to the diverse values and artefacts that are characteristic signs for the organization (Wójtowicz, 2004).

The primary determinants of intercultural management are organizational culture (understood as a derivative of culture, which operates the organization) and manager, i.e., which culture he/she comes from, what personality, temperament,

${ }^{1}$ Comprehensive information about the course, the methodology and results of research at IBM provides position G. Hofstede, 2007. 
emotional intelligence, adaptability he/she has (Szaban, 2003). Interdependencies among these elements are shown in Figure 2.

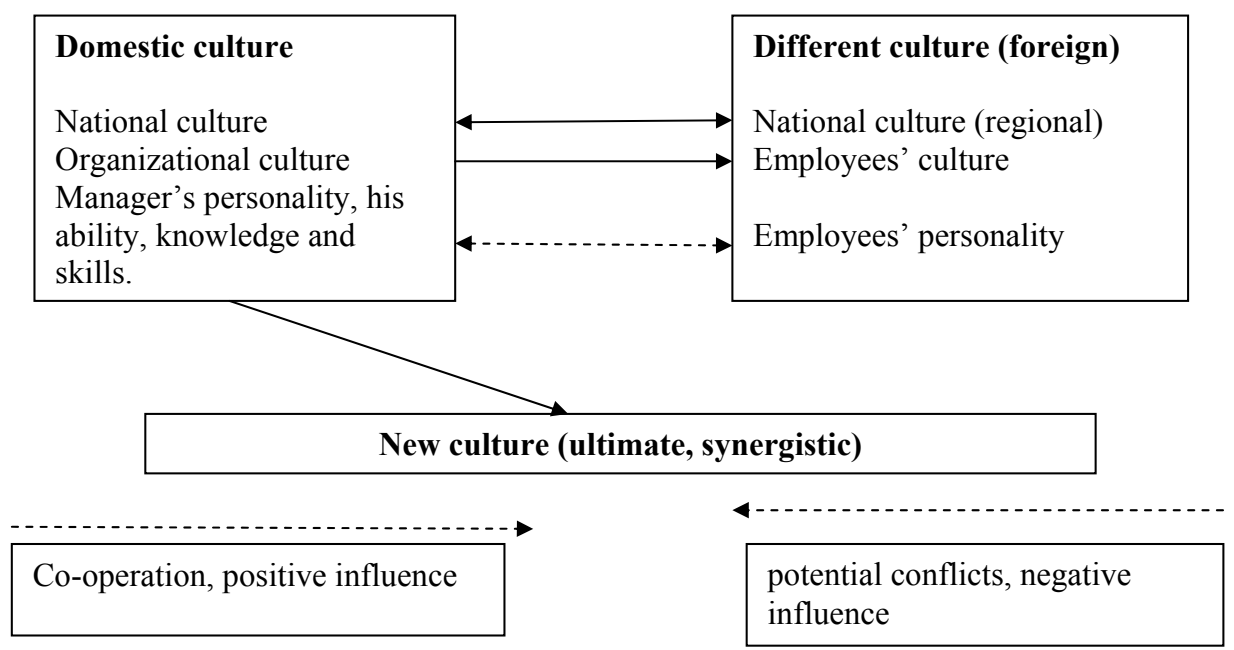

POSITIVE ORGANIZATIONAL CULTURE

Kamila Mazur

Figure 2. Conditions of intercultural management Source: Szaban (2003).

In examining the impact of cultural diversity on multi-country global companies, it becomes clear that national cultural differences are important, but their relative influence on the management of the organization depends on the phase of business development, industry and world economy. Based on the model, which is shown in Table 1, which tracks global business development can be seen marked fluctuations in the relative importance of the impact of cultural diversity on business and thus, consistently the same clear differences in choosing the most suitable approach to personnel management scale output (Adler and Ghadar, 2002). While, historically evolved sequence, originally relying on the "age of the organization" and origin as Asian, European or North American company, the order presented in the table below reflects the evolution most common for companies in the U.S.. At present, more and more transnational dynamics defines global competitiveness of business, which affects the company jump phases up to such a position that will allow them to maximize their global competitiveness in specific industries (Adler, 2002).

An extremely important aspect of effective intercultural management in the enterprise is to know the dimensions, which differ in the global culture. Over the past 30 years, a considerable number of studies has focused its attention on methods of identification and classification of cultural dimensions. Determination of the basic dimensions or characteristics of different cultures is the first and most important step to understanding them. 
POSITIVE ORGANIZATIONAL CULTURE

Kamila Mazur
The most widely known are the results of tests carried out by a Dutch researcher Geert Hofstede. Based on the analysis of questionnaires from approximately 100,000 respondents in over 50 countries, Hofstede identified five main dimensions that differentiate cultures: power distance, uncertainty avoidance, individualism-collectivism, masculinity-femininity and long-and short-term orientation. Hoftede's job became the benchmark and the starting point for most of the work on the world's cultures. What is very important Hofstede's study showed that the national culture from which the employees of multinational companies come from, produces greater differences in values, attitudes and relationships than the position occupied in the organization. Therefore, knowing the characteristics of the particular culture in the five dimensions of Hofstede, you can specify the likely behaviour, habits and traditions, which gives the possibility to plan an effective strategy for intercultural management in the enterprise and to develop a transnational culture of synergy, which arises as a result of cooperation between the representatives of a foreign culture with the culture of the home. The condition for the existence of such an effective collaboration is an attitude of openness that leads to the exploration of various combinations of elements of their course of action with elements of different modes of action. The result of such a stance is the existence of cultural synergy. The result is a new, unique organizational solutions, optimally adapted to the changed conditions of the new organization, which come from different cultures (Wójtowicz, 2004).

Another interesting concept of creating an organizational culture of companies can be found in the research on Positive Organizational Potential carried out at the Faculty of Economic Sciences and Management, Nicholas Copernicus University in Torun (Stankiewicz, 2010). The study highlights the components that create the Positive Organizational Potential. One of them is Positive Organizational Culture. Taking into consideration the earlier discussion about globalization, which is prevalent perception of enterprise and national management as a component of effective intercultural management, and internationalization, as a manifestation of an enterprise growth, findings about the values that create a Positive Organizational Culture are becoming particularly important in different, especially culturally different, countries.

The concept of the Positive Organizational Potential, climate and culture are conditioned to a specific system of business resources, tangible and intangible. The structure of these resources understood as a state, level or configuration which contain an incentive for creating a positive culture and climate of the organization play the role of initial cells which cause an enterprise's development (Stankiewicz, 2010).

The research conducted by scientists from Torun arouse interest because they bring new quality to the concept of intercultural management. So far, most studies have focused on the dimensions identified by Hofstede. What is crucial, Positive 


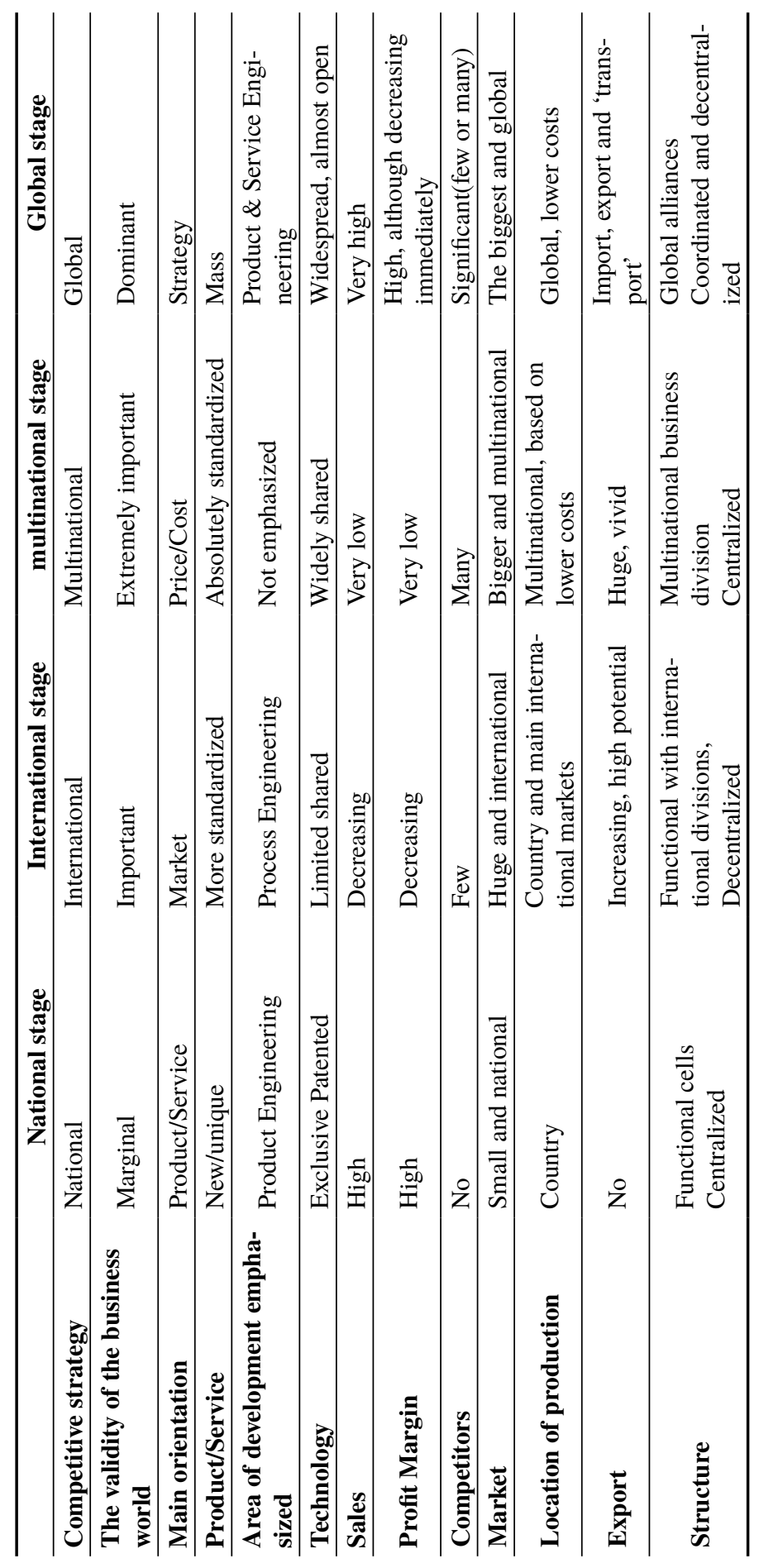

POSITIVE

ORGANIZATIONAL

CULTURE

Kamila Mazur

Table 1.

Evolution of multinational

enterprises

Source: Adler (2002)

- 71 
POSITIVE ORGANIZATIONAL CULTURE

Kamila Mazur
Organizational Culture consists in examining those values which give happiness to people and stimulate their proactive employee behaviour, aspire to excellence, creative energy or a positive relationship between employees and the company. This perspective differs significantly from the current concepts, which lay the greatest emphasis on the avoidance of cross-cultural conflicts in multinational enterprises rather than on an examination of values underlying the positive effects in the organization of different cultures.

The scientists invited 103 Polish companies and 30 companies from abroad, mostly from France, Germany and Japan to participate in the research on the Positive Organizational Potential. The survey allowed to identify, enumerate and characterize 19 components of Positive Organizational Culture (Stankiewicz, 2010). In the next part of this article the author tries to describe the values that create a Positive Organizational Culture in Japan as the determinants of effective cross-cultural management. Conclusions will be referenced to the values declared by Polish companies. Japan was chosen because it differs culturally most from the European countries and, at the same time, we can see more and more divisions of Japanese companies doing business in Poland.

In the set of fundamental values creating a Positive Organizational Culture, Japanese respondents rated highest justice (average 85), on the next position in the ranking occupied: respect for the truth (78.3), courage (65), nobleness (66.6) and honesty (58.3). Extremely interesting is the fact that honesty - the value rated highest by companies operating in Poland, was the lowest one in the ranking of by Japanese companies. Another significant difference is the average distance between successive assessments, in companies operating in Poland, the first three values differ only by low values in the average ratings (honesty -76.35 ; respect for the truth -72.31 ; justice - 71.83). In the Japanese companies the distance among the most important and the following values is much greater.

Another researched values are the values that generate positive energy in the company. In this dimension Japanese rated pro-activeness highest (75), than they pointed at: creativity (73.3), adaptiveness (68.3) and openness (61.6). Also in this case we can observe the opposite valuation, because the companies operating in Poland have assessed openness as the main value of creating positive energy in the company (average 64.8). These differences in the assessments were not as significant. Self-resistant in expression of emotions, and conservatism is one of the key features of the Japanese culture. European managers should bear it in their mind while creating cross-cultural teams in organizations and prepare their employees for cooperation with Asian colleagues.

In terms of forming positive relationships between the organization and workers, Japanese companies recognized loyalty (83.3) as the most important and as well as respect for the tradition of organization (78.3). In this case, the order of the values did not differ significantly from those of Polish companies, which 
deemed that it is important to respect the traditions (72.31) and loyalty (71.92). The high rating, given by the Japanese companies, to loyalty is closely linked with a high degree of collectivism and long-term orientation in this culture.

The Japanese tendency to achieve business excellence in organization is well known around the world. . Therefore, the scores, admitted by Japanese companies, to the values associated with these category are extremely interesting. The most important value in the pursuit of business excellence is responsibility (81.66), than in the decreasing order: commitment (80), rationality (75), excellence (63.33) and trustworthiness (70.33). It is the only category of values creating a Positive Organizational Culture in which companies operating in Poland and Japan have set the same hierarchy of the first three values. Interestingly, none of these cultures consider perfection itself as the most important value among the values that create business excellence.

In all the aforementioned dimensions Japanese companies tend to give higher scores than companies operating in Poland. Among Japanese companies we can find much more frequently an extremely positive evaluation. This may be related to a high degree of collectivism in Japanese culture and a strong relationship with the organization in which they work. In the Polish culture the company is perceived simply as a place of work and source of income. In Japan, the organization is like a second family to which employees become intimate.

By identifying the values with the highest intensity in the country, we can attempt to characterize national cultures.

\begin{tabular}{ll}
\hline & Top rated validity of values: \\
\hline Among Polish respondents & Among Japanese company representatives \\
\hline 1. honesty & 1. justice \\
\hline 2. responsibility & 2. loyalty \\
\hline 3. respect for organizational traditions & 3. responsibility \\
\hline 4. respect for truth & 4. commitment \\
\hline 5. loyalty & 5. respect for organizational traditions \\
\hline
\end{tabular}

In both of the national groups we can find only two common values: loyalty and respect for organizational traditions which indicates the existence of significant differences among these cultures. The Polish companies put more emphasis on basic values, while the Japanese on ones that build employee loyalty to the organization (Glińska-Neweś, 2010).

This article presents only the basic theoretical assumptions about effective intercultural management in the enterprise and shows the new concepts in it. It is important that the manager should, in some sense, follow their subordinates. As the reference point he/she should work out the cultural background of
POSITIVE ORGANIZATIONAL CULTURE

Kamila Mazur 
POSITIVE ORGANIZATIONAL CULTURE

Kamila Mazur their employees and build a Positive Organizational Culture through Positive Organizational Potential.

In today's business world, gaining competitive advantage based on technology or the price is rather insufficient. A sustainable advantage in the market is increasingly turning to surface cultural factors. This is a strong argument in favour of taking into account cultural factors in the strategic planning and business management.

\section{References}

Adler N.J., Ghadar F. (2002), "International Strategy from the Perspective of People and Culture: The North American Context" in: N.J. Adler (Ed.) International Dimensions of Organizational Behavior, Canada 2002, , p. 179-205

Adler N.J. (2002), International Dimensions of Organizational Behavior, Canada.

Glińska-Neweś A., (2010) Pozytywna Kultura Organizacyjna jako pożądany efekt Pozytywnego Potencjału Organizacji, in: M.J.Stankiewicz (ed.) Pozytywny Potencjat Organizacji. Wstęp do użytecznej teorii zarządzania, „Dom Organizatora” TNOiK, Toruń, pp. 75-106

Gudykunst W. B., Ting-Toomey S., (1988) Culture and interpersonal communication, Thousand Oaks.

Hofstede G., Bond M. (1988), 'The Confucius connection: From Cultural Roots to Economic Growth', Organizational Dynamics, vol. 16, no. 4,.

Hofstede G. (2007), Kultury i organizacje : zaprogramowanie umysłu, PWE, Warsaw,.

Karcz M. (2001), "Międzykulturowe badania zachowań podmiotów rynkowych - problemy metodologiczne" in: J. Kramer, E. Zeman-Miszewska (eds.), Konsument i przedsiębiorstwo w otoczeniu wielokulturowym - podstawy teoretyczno-metodyczne, decyzje marketingowe, Wydawnictwo Akademii Ekonomicznej w Katowicach, Katowice.

Kostera M.(2003), Antropologia organizacji: Metodologia badań terenowych, PWN, Warsaw.

Northouse P.G. (2007), Leadership. Theory and Practice, London.

Sikorski Cz. (2002), Kultura organizacyjna. Efektywnie wykorzystaj możliwości swoich pracowników, C.H. Beck, Warsaw.

Smircich L. (1983), Concepts of Culture and Organizational Analysis, 'Administrative Science Quarterly', Vol. 28, part. 3,.

Stankiewicz, M.J (ed.) (2010), Pozytywny Potencjat Organizacji. Wstęp do użytecznej teorii zarzadzania., Dom Organizatora TNOiK, Toruń.

Szaban J. (2003), Miękkie zarzqdzanie. Ze współczesnych problemów zarzq̨dzania ludźmi, Wydawnictwo WSPiZ im L. Koźmińskiego, Warsaw.

Witkowski M. (2007), Menedżer czy antropolog? Jak powstaje dyskurs międzykulturowego marketingu i zarządzania, Dąbrowa Gónicza.

Wójtowicz A. (2004), "Diagnozowanie kultury organizacyjnej w zarządzaniu międzykulturowym" in: L. Zbień-Maciąg, D. Lewicka (eds.) Poszukiwanie tożsamości organizacyjnej w jednoczacej się Europie, (ed.), Uczelniane Wydawnictwa NaukowoDydaktyczne, Cracow. 